\title{
O SENAI E A EDUCAÇÃO PROFISSIONALIZANTE NO BRASIL
}

\author{
Meire Terezinha Müller \\ Faculdade de Americana - FAM \\ meiremuller@hotmail.com
}

\begin{abstract}
RESUMO
O presente artigo discorre sobre a criação do SENAI no Brasil em 1942, após muitas outras iniciativas públicas e privadas de formação profissional voltadas a crianças e jovens. A questão da profissionalização no país é um tema bastante caro aos governantes, que remonta à chegada da Família Real em 1808. A abertura de cursos de formação de ofícios foi uma das primeiras ações do Príncipe Regente em terras brasileiras, o que comprova que a formação profissional - desde sua gênese destinada às massas - sempre serviu para prover ou manter o conforto das elites que puderam optar pela educação intelectual, dualismo que permeia nosso sistema educacional ainda hoje. O panorama econômico, político e social que levou à criação do SENAI em 1942 mostra que, atrelada à necessidade de se reproduzir operários para o parque industrial brasileiro cada vez maior a partir de 1930, a formação profissionalizante carrega em seu bojo toda uma estrutura hierarquizada, constituindo-se a fábrica num microcosmo social, no qual se reproduzem as condições de dominação e subordinação, de repressão, obediência, resistência e luta de classes.

Palavras-chave: SENAI; Educação profissionalizante; Educação e Trabalho.
\end{abstract}

\section{SENAI AND THE PROFESSIONAL EDUCATION IN BRAZIL}

\begin{abstract}
This article discusses the creation of SENAI- Serviço Nacional de Aprendizagem Industrial in Brazil, after many other public and private vocational training of children and teenagers. The professional education in Brazil is a subject very important to the State, dating back to the arrival of the Royal Family in 1808. The opening of training courses for trades was one of the first actions of the Prince Regent in Brazilian lands, which proves that the training was directed, since its beginning, to the poor and it has always served to provide or maintain the comfort of elites who might choose intellectual education instead of professional education - dualism that pervades our education system until today. The economic, political and social outlook, that has culminated with the creation of SENAI in 1942 shows that, linked to the need to provide workers to the industrial pool, which increased after 1930, the vocational education carries in its wake an entire hierarchical structure, becoming the factory a social microcosm, which reproduces conditions of domination and subordination, repression, obedience, endurance and class struggle.
\end{abstract}

Keywords: SENAI; Professional education; Education and Work.

\section{Introdução}

Este artigo tem por objetivo fazer uma sucinta retrospectiva crítico-histórica de alguns aspectos da formação profissional no Brasil, abordando iniciativas públicas e privadas que culminaram com a criação do SENAI - Serviço Nacional de Aprendizagem Industrial, em 1942. 
Ensinar a trabalhar e a produzir os bens necessários ao conforto e à sobrevivência humana tem sido uma prática inerente às diversas sociedades, sendo esses conhecimentos transmitidos de geração a geração, através da observação e do empirismo, desde as mais remotas eras. Entretanto, instituições escolares - no sentido moderno da expressão específicas para o ensino profissionalizante, são muito mais recentes.

A formação profissional no Brasil, desde a atuação dos jesuítas, sempre foi entendida como uma modalidade reservada às classes populares, aos caboclos, aos portugueses pobres, aos escravos e aos índios, que deveriam ocupar-se do "saber-fazer" e de quem dependeria a normalidade da vida cotidiana. Segundo Cunha (2005a), esse pensamento é uma característica da cultura ocidental, herança dos antigos gregos, que teriam inaugurado a crença de que a contemplação era própria dos sábios enquanto que a ação e o trabalho eram função dos tolos.

O próprio Aristóteles, em sua magistral obra A política destaca esse dualismo. Para ele,

[...] Entre as pessoas que estão em servidão, é preciso contar os trabalhadores manuais que vivem, como indica seu nome, do trabalho de suas mãos e os artesãos que se ocupam dos ofícios sórdidos [...] Não devemos contar entre os cidadãos aqueles que exercem profissões mecânicas ou comerciais, sendo esse gênero de vida ignóbil e contrário à virtude; nem mesmo os lavradores, pois é preciso mais lazer do que eles têm para adquirir virtudes e para o exercício dos cargos civis (ARISTÓTELES, 2009, p. 37-69)

Esse pensamento permeou toda a Idade Média e, importada, chegou ao Brasil nas caravelas portuguesas.

Com a descoberta das Américas e a expansão da escravidão nesse continente, o dualismo trabalho intelectual versus trabalho físico expandiu-se ainda mais: a representação social das atividades laborais braçais criou um preconceito tão acirrado na sociedade colonial brasileira — com resquícios que perduram até a atualidade — que, quando conseguiam eventualmente mudar seu status social, os mulatos, brancos pobres e mesmo os escravos alforriados se afastavam desse tipo de trabalho. Ao libertar-se, ou ser liberto, o escravo tentava com afinco desvincular-se o mais possível da condição de trabalhador braçal, afastando-se dos ofícios manuais e, se possível, comprando escravos para executá-los e, assim, convalidar seu novo lugar social (CUNHA, 2005a).

Como conseqüência dessa mentalidade, os ofícios manuais restavam àqueles que não tivessem nenhuma outra opção: os pobres, os desvalidos, os órfãos, os criminosos e outros desafortunados. Quem podia escolher, enveredava pelos caminhos da educação intelectual ou do comércio.

Nos primeiros anos de nossa colonização, a educação e o acesso ao saber eram destinados a uma pequena minoria, representada pelas elites agrárias, existindo, em paralelo, enormes contingentes de analfabetos, advindos da visão excludente própria da sociedade escravista do período. Maestri apud Castanho (2006) chama ao "adestramento" dessa massa para atuar diretamente no trabalho servil de "pedagogia da escravidão", ou seja, aquela em que a preparação para o desenvolvimento de determinadas funções se dá pelo medo, pela falta de opções, pela coação física e ameaças.

$\mathrm{Na}$ maioria das vezes, a aprendizagem laboral se dava no próprio lar, nas fazendas, nos engenhos, nas oficinas ou nos colégios jesuítas, onde os religiosos, desde o início de sua atuação "se improvisavam em mestres de ofícios e ensinavam [...] 'sem mais conhecimento do ofício’ como frisa o padre Fernão Cardim” (FONSECA, 1986, p.65). 
Assim, a primeira concepção pedagógica presente no Brasil, de acordo com a classificação de Saviani (2005, p.32) foi a "pedagogia brasílica", ou seja, aquela que oferecia, além do ensino do português, da doutrina cristã e do canto orfeônico - comum a todos - o aprendizado profissional e agrícola para aqueles que herdariam as funções braçais, ou a gramática latina para os que prosseguiriam os estudos superiores na Europa, "principalmente na Universidade de Coimbra".

Uma primeira iniciativa formal para o ensino de profissões, que data dos primórdios da colonização, são as assim chamadas Corporações de Ofícios, (ou "guildas"). Eram basicamente organizações ou clubes de serviços formados por trabalhadores que exerciam um mesmo ofício. Quase sempre os "ofícios" eram tarefas artesanais, como aquelas inerentes às olarias, às carpintarias e à construção civil, nas quais era exigida força física e habilidade. Essas associações sobreviviam a partir de um patrimônio comum, formado pelas cotas pagas pelos seus membros, destinado a socorrer os associados em situações de necessidade financeira, doenças ou funerais. As mais organizadas tinham um santo protetor ou "patrono" da devoção dos operários, como São José, patrono dos pedreiros, carpinteiros e marceneiros; São Crispim e São Crispiniano, padroeiros dos sapateiros $^{2}$ e São Jorge, protetor dos ferreiros, serralheiros, latoeiros, funileiros e seleiros.

Presentes na Europa desde o Império Romano, as Corporações de Ofício tinham como principal objetivo a regulamentação do processo produtivo artesanal. No Brasil, tomaram forma própria, em virtude da predominância do trabalho escravo, da indústria caseira, da escassez de artífices livres e da própria estrutura comercial local.

Além de atuar como "prestadoras de serviços", as Corporações tinham como meta a transmissão do aprendizado de um determinado ofício, ensinado pelos mestres da Corporação (mais alto posto da hierarquia) que eram também encarregados de oferecer e contratar trabalhos, julgar atritos surgidos entre os membros da irmandade e aplicar provas aos membros menos qualificados.

As Corporações de Ofício viram seu prestígio fenecer com a política econômica da Coroa Portuguesa que, a partir de tratados com a Inglaterra, proibia o exercício de determinadas funções (como tecelões ou ourives), impossibilitando o agrupamento dos trabalhadores, além da grande entrada de produtos importados no Brasil a partir da “abertura dos portos às Nações Amigas", pela carta régia de 28 de janeiro de 1808.

As Corporações de Ofício foram totalmente extintas pela Constituição Imperial de 1824 pelo Imperador D. Pedro I. A formação profissional já seguia, há algum tempo, outros caminhos.

Em 1809, apenas um ano depois da chegada da família real ao Brasil, o Príncipe Regente e futuro rei Dom João, criou o Colégio das Fábricas, no porto do Rio de Janeiro, "para formação de artífices e aprendizes" e que parece ser "a primeira intervenção governamental em direção à profissionalização de jovens”. (BRASIL/MEC, 2000, p.6768). Segundo o decreto de criação, de 23/03/1809, os artífices seriam pagos com o valor da venda dos produtos ali fabricados. Na verdade, o Colégio das Fábricas era um nome genérico que compreendia dez unidades escolares, em diferentes endereços, com oito aulas optativas em oficinas - nas áreas de trabalhos com tecidos, serralheria e carpintaria - e duas aulas obrigatórias: desenho e música. Porém, como afirma Cunha (2005a, p. 76)

o Colégio das Fábricas não prosperou. A concorrência inglesa e os interesses "internacionais" do comércio português não induziram ao surgimento de estabelecimentos industriais, pelo menos na velocidade esperada. 
Desativado em 1812, as máquinas e o mobiliário existentes no Colégio das Fábricas foram vendidos ou cedidos a particulares.

Do ponto de vista cultural e educacional, a transformação do Brasil em sede do governo português propiciou um novo olhar do Estado para as escolas então existentes : foram implantados cursos superiores, antes proibidos pela política metropolitana. Essa medida tem uma explicação óbvia quando nos lembramos de que a chegada de tantas pessoas à colônia inevitavelmente implicaria em maior necessidade de bens indispensáveis à sua acomodação e sobrevivência. Portanto, o objetivo principal da abertura de cursos era a formação de profissionais necessários à manutenção da vida quotidiana da Corte e de especialistas preparados para conflitos bélicos.

Assim, foram criadas no Rio de Janeiro, cadeiras de anatomia e cirurgia, em 1808; a Academia da Marinha, no mesmo ano; a Academia Real Militar, em 1810; o curso de agricultura, em 1814 e o curso de desenho técnico, em 1818.

Interessante lembrar que, em 1816 foi criada a Escola Real de Ciências, Artes e Ofícios, para dar subsídios à famosa missão cultural francesa, convocada e patrocinada por D. João VI, para o maior levantamento artístico até então realizado sobre as singularidades e características pitorescas do Brasil.

Após a independência, em 1822, a Escola Real teve seu nome alterado para Academia Imperial de Belas Artes - AIBA. Embora tivesse sido pensada para atuar nos mesmos moldes das academias europeias - com o ensino das belas-artes em sintonia com o das Ciências, do Desenho e Ofícios Mecânicos - essa intenção não se concretizou num primeiro momento. Apenas em 1855 a Academia de Belas-Artes passou a ter cursos estruturados, com os alunos divididos em dois grupos: os artistas, que se dedicavam às belas-artes e os artífices, que se dedicavam às artes mecânicas (CUNHA, 2005a). O que se verifica, portanto, é que - desde os primórdios - há uma divisão entre os artistas e os artífices numa classificação discriminatória que divide aquele que produz o belo, a arte (a formação intelectual) e aquele que produz bens de consumo (a formação profissional).

Segundo Oliveira (s.d), nos primeiros anos do regime imperial, o ensino profissionalizante continuava sendo aquilo que fora no período colonial: o lugar dos excluídos. Fonseca (1986, p.135) também ratifica esse pensamento, nos informando que

no tocante ao ensino de ofícios, porém, nenhum progresso havia sido feito com a mudança operada no regime político ou com as discussões ocorridas na Constituinte. A mesma mentalidade, o mesmo pensamento de destinar aquele ramo de ensino aos humildes, aos pobres, aos desvalidos, continuava a imperar.

Fonseca (ibidem) ainda assegura que a discriminação através da educação profissionalizante quase se tornou um preceito legal no Brasil, já que o artigo 124 do Projeto de Constituição para o Império do Brasil (1823), retirado da Constituição promulgada em 1824, previa que o império teria "igualmente cuidado de criar estabelecimentos para a catequese e civilização dos índios, emancipação lenta dos negros e sua educação religiosa e industrial".

O decreto Imperial de 15 de outubro de 1827 , em seu artigo $1^{\circ}$, pela primeira vez reconhece a educação como um sistema de vários níveis de ensino, que deveria ser acessível ao maior número possível de crianças. A atribuição à escola de responsabilidades inerentes ao Estado já se faz sentir nessa primeira tentativa de organização do conjunto da educação brasileira, uma vez que surge, pela primeira vez, o discurso da necessidade de escolarização e a consequente diminuição do analfabetismo como medidas preventivas ao emperramento do progresso do país. 
Essa crença, ali inaugurada, foi se fundindo àquela de que a capacitação para o trabalho e a ocupação de indivíduos pobres resguardaria a sociedade dos riscos que os desocupados poderiam significar. Se considerarmos os postulados no artigo 295 do Código Criminal do Império, de 1830, veremos aí descritos os "crimes de vadiagem", aos quais poderiam ser aplicadas penas severas, sendo passível de prisão todo aquele que "não tomar [...] qualquer ocupação honesta e útil de que possa subsistir [...] não tendo renda suficiente" (www.jus.com.br/doutrina). Ou seja, atribuía-se ao sujeito o fato criminoso (grifo nosso) de ele não dispor de "renda suficiente", pelo que poderia ser preso, mostrando-nos os princípios liberais em toda sua força.

Assim, sob a ótica dos governantes, torna-se inegável a necessidade de estabelecimentos de ensino que exercessem, ao mesmo tempo, a dupla função deles esperada: a retirada de jovens desocupados das ruas para ensinar-lhes um ofício e também livrá-los da prisão. O discurso então enraizado na Europa e nos Estados Unidos, vinculando a educação e o trabalho à manutenção da ordem social, encontrou eco no território brasileiro, adaptando-se totalmente à nossa realidade. Porém, o endereçamento das escolas profissionalizantes aos "órfãos, pobres e desvalidos da fortuna" não pode ser visto apenas como uma falha de nosso sistema educacional, mas uma realidade com a qual se tinha que lidar, inserida num contexto social mais amplo e muito novo - o surgimento das cidades - permeado por séculos de exploração e trabalho cativo. Como bem aponta Castanho (2006, p.5)

[...] o desenvolvimento precário das forças produtivas do capitalismo no Brasil, até ao fim do Império e começo da República, conjugado com relações de produção também pouco desenvolvidas, convivendo com a escravidão durante todo o período colonial e praticamente todo o Império, deixava aos agentes da política de formação para o trabalho poucas opções. Fez-se o que era possível fazer - e nem sempre da melhor maneira.

Na década de 1830, ocorreu a abertura de cursos de formação profissionalizante criados pelas academias militares do Rio de Janeiro, com o objetivo declarado de manutenção de seus arsenais e destinados exclusivamente à infância pobre. A disciplina era militar, embora os cursos por elas mantidos não tivessem caráter correcional. No ano de sua criação, Cunha (2005a p.110) nos informa que o Arsenal da Guerra contava com mais de "duzentos jovens praticando os mais diversos ofícios".

Nos anos 40 do século XIX, em Belém do Pará ocorreu a implantação da primeira Casa de Educandos Artífices, com o recorrente propósito de atendimento a crianças desamparadas e "outros desvalidos da fortuna". Escolas similares foram sendo espalhadas pelas demais províncias, com o objetivo comum de diminuir a criminalidade e a ociosidade advindas, segundo se acreditava, do desamparo dos menores. Até 1865, Cunha (2005a) e Fonseca (1986) nos informam que haviam sido criadas, pelos presidentes das províncias, dez casas nesses mesmos moldes, mantidas integralmente pelo Estado, com características mais próximas à filantropia do que à instrução pública.

Assim, enquanto as elites contratavam preceptores para a educação doméstica de seus filhos, às crianças e jovens pobres restava o ensino das primeiras letras já atrelado ao mundo do trabalho, fazendo surgir ou reforçar a irremediável e duradoura desqualificação do trabalho manual em detrimento da formação intelectual.

Em meados do século XIX, surgiram as Sociedades Propagadoras da Instrução Popular, para ministrar cursos de artes e ofícios, oferecendo a filhos de camponeses e operários "um ensino prático, teórico e de iniciação ao ensino industrial" (BRASIL/MEC, 
2000, p.68). Organizadas pela sociedade civil e mantidas pelas elites (burocratas, fazendeiros e comerciantes), essas Sociedades visavam implantar no Brasil os Liceus de Artes e Ofícios, modelo então em voga na França ${ }^{3}$. O primeiro deles foi fundado no Rio de Janeiro em 1858, seguido pelo da Bahia, em 1872 e de São Paulo, em $1873^{4}$.

Moraes (1990) esclarece que a Sociedade Propagadora de São Paulo inovou ao criar, em 1874, aulas noturnas dirigidas a todas as camadas da sociedade, tentando "ministrar, por meio de cursos noturnos gratuitos, os conhecimentos indispensáveis ao cidadão e ao operário" (grifo nosso), apresentando

aos estabelecimentos da indústria, operários inteligentes, morigerados, amigos do trabalho e, como infalível corolário de tais premissas, melhores produtores e de mais fácil direção, porque sobre eles atuará o espírito do pundonor, que não se encontra no homem-máquina (MORAES, 1990, p.45).

Embora se perceba, nesse discurso, o distanciamento entre o "cidadão" (o homem da elite) e o "operário" (o trabalhador das classes populares) pela primeira vez ambos são chamados ao mesmo local já que, na Escola da Propagadora, o ensino profissional não se encontrava vinculado à caridade e filantropia, mas à preparação de operários, necessários para atender à demanda do mercado industrial em franca constituição.

Em 1883, segundo Isaú (2006), num período de grande agitação política e social, com movimentos que desembocariam na proclamação da República e na abolição dos escravos, chegava ao Brasil a primeira missão Salesiana, vinda do Uruguai.

Seguidores dos ensinamentos de Dom Bosco ${ }^{5}$, os salesianos eram vistos como praticantes de uma modalidade atualizada da instrução jesuíta. Dom Bosco havia iniciado um trabalho de profissionalização de menores em 1853, na Itália, cujo principal objetivo era retirar crianças das ruas, dando-lhes instrução e preparando-os para o trabalho, através da "educação preventiva" que se utilizava do diálogo e de "uma amorosa assistência nos recreios, nas aulas e nos trabalhos" (DOM BOSCO apud CUNHA, 2005b, p. 52). No final do século XIX os salesianos já haviam inaugurado escolas em Niterói, São Paulo, Campinas, Lorena, Cuiabá, Recife, Salvador e Rio Grande, tendo, em 1904, dezesseis unidades espalhadas pelo Brasil. ${ }^{6}$

Portanto, no limiar da República, podemos perceber a presença de escolas profissionalizantes criadas e mantidas pelo Estado, sociedade civil ou igreja, quase sempre com características próprias da filantropia. A educação, no final do Império, portanto, servia de alicerce à manutenção de duas classes sociais distintas: a dos doutores, formada pelos intelectuais e burocratas, a quem estavam destinados os cargos de comando, os postos políticos e a administração financeira do país e a dos operários, formada pelos filhos das massas populares, quase sempre analfabetos ou minimamente letrados, a quem caberiam as tarefas braçais, indesejadas, pesadas e mal pagas.

\section{Iniciativas pós República}

No início do período republicano, Rui Barbosa, então ministro da Fazenda, promoveu uma reforma financeira visando à abertura de empresas. A euforia causada pela possibilidade da riqueza imediata levou a um caos econômico e inflação sem precedentes, período conhecido como "encilhamento", um jargão das corridas de cavalos, que nomeia o momento em que os animais, prontos, se preparam ansiosamente para a largada.

Embora tendo esse aspecto altamente negativo à economia, não se pode negar que essa "injeção monetária" como Gorender (1981) se refere ao período, foi responsável pelo 
surgimento de várias empresas e, em seu bojo, da necessidade da criação de escolas profissionalizantes que pudessem capacitar operários para suprir a demanda advinda do crescimento do parque industrial. Assim é que, em 20 de dezembro de 1906, foi apresentada à Câmara dos Deputados a proposição 195, que tratava, pela primeira vez, da criação de escolas técnicas com recursos específicos para aquele fim. O presidente então empossado, Afonso Pena (1906-1909) mostrara-se favorável à criação de escolas de formação profissional em nível primário - único acessível às massas proletárias afirmando que essas instituições "muito podem contribuir também para o progresso das indústrias, proporcionando-lhes mestres e operários instruídos e hábeis" (FONSECA 1986, p.172).

Foram então fundadas Escolas Comerciais em São Paulo, Rio de Janeiro e Bahia, além de se proceder a uma reorganização do ensino agrícola que deveria formar "chefes de cultura, administradores e capatazes" (FONSECA, 1986, p.173).

No início do século XX, a incipiente indústria brasileira contava apenas com uma produção rústica e artesanal, sendo que, assim, a formação profissional estava ligada a um "adestramento" para o trabalho das manufaturas, porém os cursos eram totalmente desvinculados da formação teórica.

Em 1909, Nilo Peçanha, em sua breve passagem pela Presidência (1909/1910) instalou uma rede de 19 Escolas profissionalizantes chamadas de Escolas de Aprendizes Artífices nas capitais dos estados, destinadas ao ensino industrial, criadas nos mesmos moldes dos Liceus de Artes e Ofícios e custeadas pelo Estado.

Político influenciado pelo industrialismo, Peçanha acreditava que "o Brasil da bela época sairá das academias, mas o Brasil do futuro sairá das oficinas" (LAURINDO, 1962, p.21). Embora tenha se firmado dentre os estudiosos do tema como um presidente preocupado em impulsionar o ensino técnico-profissional, é fato que a justificativa para a criação das escolas apresentava a mesma mentalidade assistencialista de outras iniciativas, além do preconceito contra os filhos das "classes proletárias" que seriam, segundo declarado nos "Considerandos" do Decreto 7.566 de 23/09/1909 - criação das escolas "mais facilmente cooptados pelo crime, mais propensos à mendicância e ao ócio", o que tornaria "necessário não só habilitar os filhos dos desfavorecidos da fortuna com o indispensável preparo técnico e intelectual, como fazê-los adquirir hábitos de trabalho profícuo, que os afastará da ociosidade, escola do vício e do crime".

As Escolas de Aprendizes Artífices foram regulamentadas pelo presidente Hermes da Fonseca (1909-1914) em seu Decreto 9.070 de 25/10/1911, mantendo ainda a visão redentora do trabalho e das escolas técnicas.

Porém, nenhum outro presidente deixou tão clara a visão assistencialista dos cursos profissionalizantes quanto Venceslau Brás (1914-1918). Em um discurso proferido no Senado, o presidente declarou que, somente através do ensino profissionalizante o país conseguiria "remediar em parte os males do presente e lançar as bases para um futuro melhor", pois

a criminalidade aumenta; a vagabundagem campeia; o alcoolismo ceifa, cada vez mais, maior número de infelizes, porque, em regra, não tendo as pobres vítimas um caráter bem formado e nem preparo para superar as dificuldades da existência, tornam-se vencidos em plena mocidade e se atiram à embriaguês e ao crime (apud FONSECA, 1986, p.187).

O fato que os dados apontam, porém, é que apesar do discurso, pouco se fez pelas escolas profissionalizantes no governo de Venceslau Brás, devido à situação econômica do país no início do século XX. A diminuição na exportação de café e a primeira guerra mundial haviam imposto dificuldades econômicas que impossibilitaram a implantação das 
escolas planejadas. Em São Paulo, entretanto, nesse mesmo período, desenvolveu-se um intenso movimento industrial, que despertou o interesse e a busca por cursos técnicos. Para evitar o êxodo rural, foi promulgada a Lei Estadual 1.711 de 27 de dezembro de 1919, que estabelecia a obrigatoriedade de uma autorização para abertura e instalação de cursos profissionalizantes nas escolas já existentes, sugerindo-se que, no interior, deveriam ser abertos apenas cursos voltados a atividades agrícolas, já que cursos industriais eram compatíveis apenas com empregos conseguidos na capital.

Em meados dos anos de 1920, no governo de Epitácio Pessoa, as escolas profissionalizantes apresentavam problemas relativos às instalações, à falta de um planejamento pedagógico, de pessoal técnico para ministrar aulas nas oficinas além de diferenças estruturais de conteúdos, objetivos, duração dos cursos e grande evasão de alunos. Para tentar minimizar esses problemas, o ministro Ildefonso Simões Lopes nomeou uma comissão técnica composta, na maioria, por profissionais do Instituto Parobé (criado inicialmente como uma Escola de Aprendizes Artífices), do Rio Grande do Sul que vinha alcançando repercussão nacional pelo seu trabalho com cursos profissionalizantes. A chefia da comissão coube ao diretor do instituto, o engenheiro João Lüderitz. Em 1921, foi apresentado o relatório da comissão, propondo o desenvolvimento de ações que pudessem dar um caráter orgânico às escolas técnicas profissionalizantes, contratando, se necessário, profissionais especializados no país ou no exterior. Lüderitz, no relatório, diagnostica como principais culpados pela situação das Escolas de Aprendizes Artífices os próprios pais dos alunos, conforme esclarece Queluz (2000, p. 159)

Em vista da falta de interesse do proletário por uma educação técnica profissional propriamente dita, do que dá prova bem patente o fato de retirarem os alunos das escolas logo após a conclusão dos dois primeiros anos do curso elementar, urgia estabelecer nas escolas de Aprendizes Artífices, que a união mantém, com sacrifícios pecuniários, em 19 capitais de estados do país condições tais, que despertassem mais interesse do povo pela formação de seus filhos como operários, capazes de acompanharem os intensos progressos da técnica. Era preciso tornar o recinto da escola mais atraente.

No mesmo documento, Lüderitz ratifica os principais problemas identificados na Escolas de Aprendizes Artífices, destacando a má formação de mestres e contramestres que, salvo raras exceções, não eram capazes de realizar um ensino técnico de qualidade por não estarem habilitados para a tripla função deles exigida: o ensino prático na oficina; o desenho industrial e a tecnologia de sua área.

Quem vai ensinar os segredos das artes e dos ofícios tem que ter as duas qualidades reunidas: a do professor e a do mestre de oficina, visto que não se podem separar os conhecimentos humanísticos de redação e de contabilidade, matemáticas elementares e aplicadas, rudimentos de ciência natural, física e química elementar, etc, da imediata aplicação que tais princípios de ensino têm na organização de projetos e orçamento dos artefatos, do desenho industrial, geométrico e ornamental e da tecnologia de cada arte ou ofício (LÜDERITZ apud BRANDÃO, 2003, p.10)

A Comissão Técnica foi então transformada no Serviço de Remodelação do Ensino Profissional Técnico, basicamente composto pelos mesmos membros, para colocar em prática as sugestões apresentadas. Desta forma, Lüderitz conseguiu disseminar por todo o país sua concepção de educação profissional, diferente daquela aplicada nas Escolas de 
Aprendizes Artífices. Segundo Cunha (2000), o Serviço de Remodelação era o princípio de um processo que deveria terminar como um amplo projeto de regulamentação do ensino profissionalizante, mas que nunca foi aprovado, porque, à época, o forte movimento anarco-sindicalista assustava os proprietários das fábricas. As Escolas de Aprendizes Artífices teriam sido criadas, dentre outros objetivos, para formar uma mão-de-obra ordeira, servil, afinada com os interesses do capital; portanto, deveriam permanecer como estavam? .

A década de 1930 testemunhou importantes mudanças nos setores econômico, político e, consequentemente, educacional no Brasil que se estenderam até 1945, período conhecido como Era Vargas.

Separou-se o sistema educativo do ocupacional pela criação do Ministério da Educação e Saúde Pública (em 1930) e do Trabalho, Indústria e Comércio (no mesmo ano). No setor produtivo, porém, é que o governo de Getúlio Vargas causou o maior impacto, com o impulso inédito à industrialização através da criação da CSN - Companhia Siderúrgica Nacional e da Petrobrás, para exploração e refino de petróleo. Num governo tão voltado para o crescimento industrial, nada mais natural que a valorização da educação profissionalizante, cuja função seria a formação do operariado necessário à sua manutenção. No período foi criada, pelo Decreto 19.560 de 05/01/1931, a Inspetoria do Ensino Profissional Técnico (que após três anos passou a Superintendência ${ }^{8}$ ), ligada ao Ministério da Educação e Saúde. Uma das resoluções da Superintendência foi uma tentativa de unificar a educação profissionalizante. Para isso, deliberou que, para o desenvolvimento da formação profissional, poderiam obter reconhecimento oficial os cursos ministrados em escolas públicas ou particulares, desde que estas adotassem os currículos e organização didática das escolas federais na tentativa de atender a toda a sociedade civil e não apenas aos "desafortunados da sorte".

Em 1931, com a criação do Conselho Nacional de Educação, o governo provisório sancionou seis decretos efetivando uma ampla reforma educacional no país, conhecida como Reforma Francisco Campos, cuja justificativa era que "o mundo vive hoje sob o sinal do econômico, como já viveu em outros tempos sob o sinal do religioso e do político". Assim, os indivíduos deveriam estar preparados, técnica e profissionalmente, para a sociedade das profissões.

Ainda em 1931, estruturado nos moldes da norte-americana Taylor Society, foi criado o IDORT - Instituto de Organização Racional do Trabalho, cujo principal objetivo era divulgar o processo de trabalho apregoado por Taylor ${ }^{9}$, apresentando o taylorismo como remédio para redução de custos e aumento na produtividade das empresas. Encabeçada por um grupo de empresários, a criação do IDORT recebeu o apoio da Associação Comercial de São Paulo e da CNI - Confederação Nacional da Indústria e, como primeira medida, implantou alguns cursos de formação profissional em parceria com empresas. A partir de 1934, o IDORT dirigiu suas atividades também para a administração pública, implantando projetos em São Paulo, Paraná, Pernambuco e Goiás ${ }^{10}$.

O embate político-ideológico na área educacional arrastou-se durante toda a Era Vargas, sendo notórias as discussões entre os assim chamados Pioneiros da Educação Nova $^{11}$ que, embora com diferentes posições ideológicas, pregavam um novo modelo educacional em que a educação conseguisse atuar e interferir na sociedade brasileira através de uma escola menos academicista, mais prática, gratuita, obrigatória e laica portanto acessível às massas - o que poderia neutralizar o poder oligárquico da elite nacional. O movimento reformador encontrou forte resistência na Igreja Católica, que se sentiu ameaçada por controlar a maioria das escolas da rede privada. 
Portanto, ao reassumir a presidência da República em 1937, após o golpe que decretou o Estado Novo - um governo ditatorial, centralizado no poder Executivo - Getúlio Vargas voltou seu olhar a essa nova sociedade baseada no capitalismo industrial. O Estado centralizador e populista, gestado desde 1930, não poderia ausentar-se do debate sobre esse novo operário, passando a criar medidas para atender aos objetivos do capital através da educação, buscando a capacitação profissional a partir da implementação de políticas públicas. Assim, em 1937, o ministro Gustavo Capanema, através da Lei 378 de 13 de janeiro, dava uma nova estrutura ao Ministério da Educação, suprimindo a Superintendência do Ensino Profissional e seguindo à risca os preceitos do artigo 129 da Constituição de 10 de novembro daquele ano, onde se reafirmava a necessidade de atender à demanda da industrialização desencadeada na década de 30, sendo que os operários deveriam sair - mais uma vez - das classes "menos favorecidas".

Ainda sob a égide da visão do trabalho como restaurador e mantenedor da ordem e das virtudes, foram efetivadas, a partir de 1942, significativas mudanças educacionais, através de decretos-leis, conhecidos como "Reforma Capanema"12 ou "leis orgânicas do ensino" uma série de oito decretos, cujo principal objetivo era organizar o sistema de educação do país com vistas a adequá-lo à nova ordem econômica e social que então se configurava, carregando no seu bojo a expansão do setor terciário urbano e a constituição de novas classes sociais, como o proletariado e a burguesia industrial. A Reforma Capanema, para muitos estudiosos, oficializou a seletividade, acentuando ainda mais a elitização do ensino, pois estabelecia leis específicas à preparação intelectual ou à formação profissional para atendimento às necessidades do mercado. Através do Decreto 4.048/42 dessa Reforma, foi criado o SENAI - Serviço Nacional de Aprendizagem Industrial.

\section{A institucionalização do SENAI}

De acordo com o SENAI (2007, p. 46), antes do decreto 4.048/42 "as poucas escolas profissionais existentes respondiam pela formação de apenas $7 \%$ dos operários qualificados, sendo o restante treinado, rotineiramente, nas próprias indústrias".

Para a implantação do SENAI e delimitação de seu perfil, Vargas valeu-se principalmente do apoio de Roberto Simonsen, à época Presidente da CNI. Simonsen fora indicado pelo presidente, em 1937, para o Conselho Federal para o Comércio Exterior e havia sido membro de duas Comissões Técnicas encarregadas de apresentar ao Governo um projeto de criação de uma instituição exclusivamente voltada para a aprendizagem industrial, ou seja, um órgão privado, encarregado de criar e ministrar cursos para aprendizes e operários de várias empresas, dirigido pelos empresários e mantido com recursos vindos das indústrias através do fundo de aposentadorias e pensões.

Para os assuntos didático-pedagógicos, Simonsen indicou o engenheiro suíço Roberto Mange, entusiasta defensor do taylorismo, da psicotécnica, da formação científica e racional do trabalho. À época, Mange era diretor do Liceu de Artes e Ofícios de São Paulo, aonde vinha pondo em prática suas teorias educacionais desde 1924, quando criou um curso mecânico de Reparação de Material Rodante, com quatro anos de duração, especialmente voltado a aprendizes ferroviários. O referido curso foi aplicado no Liceu, em conjunto com a Companhia Paulista de Estradas de Ferro, a Sorocabana, a São Paulo Railway e a Companhia Mogiana de Estradas de Ferro. Cada uma dessas companhias ferroviárias, pelo convênio assinado, deveria enviar dois aprendizes para realizar o curso no Liceu, sendo a parte prática ministrada nas oficinas de uma delas. 
Uma análise sobre a trajetória profissional e acadêmica dos dois Robertos Simonsen e Mange - mostra que o SENAI surgiu muito antes de a instituição ser oficialmente criada, já que vários instrumentos naqueles moldes vinham sendo tentados por eles desde a época anterior a seu estabelecimento oficial.

A instituição do SENAI, entretanto, diferente do discurso que prega que os industriais - representados pelos dirigentes da CNI e FIESP - o teriam "idealizado" a pedido do governo, que sentia que não tinha meios de pô-lo em prática, não foi bem assim. A massa empresarial, formada por pequenos e médios empresários, não compreendeu o SENAI como um órgão pertencente a todos, mas como um peso a mais, um serviço restrito à elite empresarial, demonstrando, por isso, resistência à sua implantação, tanto por não compreenderem muito bem os seus objetivos quanto pela obrigatoriedade do recolhimento dos subsídios para sua manutenção.

Coube ao grupo ligado a Simonsen exercer o papel de mentor do projeto SENAI, não sendo considerado representativo, portanto, do todo empresarial. Confirmando sua posição de elite decisória dos caminhos da industrialização no país, esse grupo viu seu poder e prestígio aumentados por meio de relações com o governo e controle das associações dos industriais, obrigando inicialmente seus pares a manterem aprendizes em escolas profissionalizantes, a criarem CIPAs e outras medidas nem sempre simpáticas aos empresários.

Também por parte do operariado houve resistência à implantação do SENAI, talvez temendo a possibilidade de desemprego aos não participantes dos cursos ou, ainda, pelo fato de aquele órgão estar muito próximo à burguesia industrial, o que tornava os trabalhadores refratários ao processo. As associações de trabalhadores, na tentativa de minimizar conflitos de classes e fiéis ao esquema corporativista e hierárquico idealizado por Vargas para o operariado organizado, conclamavam seus membros à sindicalização procurando mantê-los na fôrma estreita estabelecida para as atividades sindicais. Os empresários, portanto, depois de um tempo atribuíram para si a criação do SENAI na esperança de assim poderem legitimar o controle que as associações patronais mantêm unilateralmente sobre a formação do proletariado industrial. "O industrial Jafet via na escola um meio para criar hábitos de consumo que aumentassem a demanda por produtos industrializados, mas considerando sua manutenção um dever do Estado". (BRYAN, 1983, p.58)

Nos primeiros anos, o SENAI (1991a) tentava incutir em seus aprendizes o objetivo de transformá-los em "cidadãos responsáveis, conscientes de suas obrigações e capazes de contribuir para o desenvolvimento industrial" (grifo nosso). Nesta mensagem, compreende-se explicitamente a visão que os industriais tinham acerca de seus trabalhadores. Foi necessário criar um órgão, para que os operários se tornassem cidadãos responsáveis e conscientes de suas obrigações, o que sinaliza que, aqueles que não fossem inseridos nos cursos do SENAI - no caso a grande maioria da massa trabalhadora continuaria sendo considerada despreparada para a cidadania e socialmente irresponsável.

O SENAI, embora não possa ser considerado fundamental para o estabelecimento de nosso parque fabril, assumiu como missão a valorização do trabalhador nacional, o que significa, em última instância, a tentativa de transformar um grupo sob seu controle em uma elite dentro da grande massa trabalhadora, colocando mais uma camada na representação social do trabalhador braçal: aquele formado pelo SENAI.

A atuação de Roberto Mange, porém, mostra um homem cheio de contradições algumas bem visíveis em seus livros, discursos, entrevistas e anotações pessoais. Ao mesmo tempo em que precisava decidir quais cursos abrir e em que locais instalar as escolas SENAI, Mange demonstrava uma grande preocupação com a formação 
humanística e a socialização dos aprendizes, assim como com sua saúde, sua família e seu bem-estar, preocupação, evidentemente, restrita àquela pequena parcela de trabalhadores que, depois de exames orais, escritos e psicotécnicos, conseguissem chegar até o SENAI.

Como material didático, instituiu a utilização das "Séries Metódicas Ocupacionais" - $\mathrm{SMO}^{13}$, ou seja, a decomposição das funções em fases, com grau crescente de dificuldade às quais os aprendizes iam tendo acesso ao vencer a série anterior. Outro ponto caro à educação pregada por Mange, era a aplicação de testes psicotécnicos, considerados uma ferramenta importante não só no processo seletivo dos alunos como também na verificação de suas aptidões ${ }^{14}$.

Para ele, os testes psicotécnicos deveriam ser específicos à realidade brasileira, uma vez que "não se pode fazer psicotécnica aplicando testes organizados num outro país" (SENAI, 1991a, p.102).

Com os testes psicotécnicos, Mange visava avaliar o desempenho do aluno em seis grandes categorias: inteligência geral; memória; apreensão e reprodução; senso técnico; acuidade dos sentidos e habilidade manual. Eram consideradas, no levantamento dos resultados, a memória para números, a compreensão e julgamento das questões propostas, o senso técnico, a percepção de formas, a acuidade visual e tátil, a coordenação motora e a habilidade manual dos candidatos em suas respostas. (MANGE, 1934, p.07).

Gabando-se de seu pioneirismo na aplicação desses testes, o SENAI e o IDORT ${ }^{15}$ patrocinaram, em 1948, o Seminário Internacional de Psicotécnica no Guarujá, que contou com a presença de psicólogos europeus e norte-americanos. Até aquele ano eram pouquíssimos os psicólogos formados no Brasil (o primeiro curso havia sido aberto em 1935, na Escola Livre de Sociologia e Política de São Paulo) o que talvez justifique a falta de um debate entre os defensores e críticos da psicologia aplicada. Sobre o tema, nos diz Weinstein (2000, p. 155) que "nas raras vezes em que os dirigentes assumiram que poderiam haver críticas à psicotécnica, salientaram que os operários brasileiros tinham características físicas, culturais e educacionais menos uniformes que os dos outros países, o que justificava sua aplicação". Porém, enquanto aqui a psicotécnica ia ganhando o status de ciência aplicada, através principalmente do SENAI, nos Estados Unidos e na Europa começava a ser criticada, levantando-se dúvidas sobre sua validade ${ }^{16}$.

Tal era o apego de Mange ao racionalismo no trabalho, que ele criou uma fórmula "científica" que pudesse representar o resultado eficiente de um trabalho: seleção + formação + adaptação = eficiência (BRYAN, 1983, p.29).

As SMO, pela sua própria característica "racional", portanto, era o material que mais eficientemente se afinou aos preceitos da racionalização e organização científica do trabalho, fundamentais - no discurso dos industriais e tecnocratas como Roberto Simonsen, Euvaldo Lodi, Morvan Dias de Figueiredo e João Lüderitz - para o desenvolvimento de seus cursos e da própria sociedade industrial, estabelecendo como que um microcosmo da sociedade na oficina. Embora as indústrias paulistas do período, em sua grande maioria, não estivessem preparadas para a introdução de métodos racionais e científicos em sua rotina profissional, o Taylorismo e o Fordismo mostravam-se muito atraentes por representarem o que havia de mais moderno e inovador nos processos industriais.

No modelo do taylorismo adotado no Brasil, a que denominamos de taylorismo tropical, a participação dos operários era mínima ou nenhuma; na verdade, o operário era o maior obstáculo à organização racional no ambiente fabril, pela sua pouca cultura, sua limitada experiência da vida econômica industrial e sua insubordinação às rígidas normas impostas por aquele modelo, sendo considerados subversivos ou ingênuos demais, dificilmente tidos como parceiros. 
A racionalização, a nosso ver, tem profundos efeitos sociais e contraria de forma patente as ideias fundamentais do marxismo. Com o objetivo de formar operários e, por extensão, seres humanos disciplinados e produtivos, a educação a serviço da racionalização perde seu olhar crítico sobre o trabalho e sobre as sociedades capitalistas, tentando justificar-se com discursos de busca do progresso, de realizações profissionais futuras e de ascensão social. De acordo com Ciavatta (2005, p. 137) "o senso comum divulga um substractum ideológico, de que o 'trabalho dignifica o homem' 'previne o vício', 'produz a riqueza nacional' e, nas famílias de baixa-renda, há a necessidade do 'ganha-pão' para a sobrevivência diária".

Nesse panorama, o SENAI foi parte de uma campanha para condicionar todas as discussões sobre o bem-estar social atrelado ao crescimento econômico e ao aumento de produtividade a partir da utilização da organização racional do trabalho. Essa campanha produziu um discurso hegemônico, cujas bases foram aceitas mesmo pelas organizações operárias mais críticas.

No entanto, se por um lado a racionalização do trabalho pretendia criar um operário obediente e submisso, que nada questionava, realizando de forma sistemática o seu trabalho, por outro tolhia-lhe a criatividade, cerceando sua capacidade de responder com presteza a situações imprevistas.

Em 1927, sobre as primeiras experiências com a racionalização do trabalho utilizadas, um artigo do Jornal independente $O$ Trabalhador Gráfico tido como combativo e com uma longa história de militância, ironizava a postura do SENAI pela "abertura de cursos de emergência para gráficos, para suprir a carência do mercado". O articulista ironiza, salientando que a "carência" se deve aos baixos salários pagos à categoria, que os afasta dos empregos, e não à falta de formação técnica. (apud WEINSTEIN, 2000, p. 219). Na edição de 1954 o mesmo jornal criticava a "fabricação em massa de linotipistas" pelo SENAI, o que acarretaria a saturação do mercado (o "exército industrial de reserva") cujo "único objetivo" seria o de "rebaixar o nível dessa categoria profissional, quer seja em seus salários, ou em sua capacidade técnico-profissional". O articulista ainda ironiza a busca pelo "progresso" através de métodos que, aparentemente, poderiam ser vantajosos para os trabalhadores, mas, numa análise mais profunda, se mostrariam totalmente voltados aos industriais: "os diversos aspectos da racionalização do operário, tendo em vista a máquina e a intensificação do trabalho humano, todos esses elementos estão indissoluvelmente unidos entre si no regime capitalista" (apud WEINSTEIN, 2000, p.67).

Na edição de 1959, a notícia sobre um congresso de metalúrgicos ocorrido em São Paulo informa ter sido encaminhada ao SENAI uma carta, solicitando a abertura de escolas em todas as cidades industriais do estado, porém, ao mesmo tempo, pedindo a participação efetiva dos sindicatos na elaboração dos referidos cursos (apud WEINSTEIN, 2000, p. 69).

Em resumo, do ponto de vista dos sindicatos, o SENAI teve importância ao estabelecer níveis profissionais e sua correspondente faixa salarial, o que impedia os industriais de pagarem salários defasados a seus operários. Por outro lado, a classificação das funções mais ou menos especializadas não era fixa, havendo uma reclassificação periódica nesses níveis, passando, muitas vezes, funções inicialmente tidas como "especializadas" para a categoria "semi-especializada", o que se refletia diretamente em uma baixa nos salários dos trabalhadores.

Com o passar do tempo, os operários começaram a receber com menos resistência as propostas do SENAI, esperando que, com o aumento da produtividade, eles também pudessem ter parte na divisão dos ganhos, representados por aumento dos salários.

Se considerarmos o SENAI como parte da estratégia dos industriais para conseguir o controle social, podemos perceber limites óbvios para suas ambições de hegemonia, mais 
facilmente verificáveis na década de 1970, principalmente com os movimentos operários de São Paulo, notadamente dos metalúrgicos, grande parte deles formada pelo SENAI.

Segundo Weinstein (2000 p. 366), em 1980 "os presidentes dos quatro maiores sindicatos operários - os mais combativos de São Paulo - eram todos ferramenteiros formados pelo SENAI, sem contar que o Presidente Luiz Inácio Lula da Silva, também formou-se torneiro mecânico lá" . Talvez o que o SENAI tenha proporcionado foram as condições para que seus alunos refletissem criticamente sobre sua própria posição no processo produtivo, levando-os à conclusão que podiam questionar e até opor-se ao rígido controle das fábricas. Portanto, se o SENAI esperava formar operários submissos e imunes à militância operária, talvez a participação de ex-alunos em movimentos sindicais seja vista como uma rebeldia indesejável ou um fracasso da instituição em buscar a paz social através da formação profissionalizante. Porém, por outro lado, talvez a participação do SENAI tenha sido importante na criação de uma consciência política coletiva daquele grupo, que - conhecendo por dentro a estrutura empresarial - passou a buscar um modelo social que não dependesse dos industriais, preferindo lutar pelo direito de mais atenção à saúde, à segurança no trabalho, por melhores salários, justiça e igualdade de condições para todos.

Com relação ao método de ensino utilizado no SENAI, até o falecimento de Mange em 1955, as SMO - Séries Metódicas Ocupacionais - tiveram papel hegemônico. Depois, juntou-se a elas a metodologia conhecida como TWI - Trainning Within Industry, criada por especialistas norte-americanos para formação acelerada de trabalhadores para as indústrias. Ambos os métodos previam a utilização de folhas de exercícios, com gradação de dificuldade na execução das tarefas, sendo um ensino praticamente individual, um "estudo dirigido", havendo entre ambos um diferencial importante: os TWI dispensavam a formação geral, centrando-se exclusivamente no aprendizado prático nas oficinas, enquanto que as SMO eram parte de um projeto muito mais amplo, em que se propunha o ensino tanto da parte teórica quanto da parte prática de disciplinas técnicas e também de formação geral. O que esses dois métodos têm em comum, além da metodologia em si, é que ambos adunam-se perfeitamente ao capitalismo, por representarem uma intensa divisão de trabalho, típica do sistema produtivo que, nesse caso, se expande, determinando a ação educativa.

A outra já citada atividade considerada importante pelo SENAI e que foi defendida por Mange durante toda sua vida foi a aplicação de testes psicotécnicos, que ofereciam aos dirigentes do órgão uma alternativa moderna e cientifica aos processos então em vigor para acesso de alunos às escolas. O SENAI (1991a, p. 47) assim se manifesta sobre os métodos anteriores à sua atuação: "essa alternativa científica vem contra os processos certamente irracionais e ineficientes que permeavam a sociedade brasileira, pela qual os indivíduos conseguiam acesso às escolas e empregos valendo-se de relações pessoais ou influência". Um dos entrevistados pelo Projeto Memória declarou que Mange fazia todo esforço para ignorar as relações sociais e políticas dos candidatos a emprego, "jogando no lixo as cartas de apresentação que normalmente apresentavam" (ibidem).

É muito difícil avaliar a abrangência e o alcance dos objetivos do SENAI. Se formos nos basear apenas no número de operários formados, levando em consideração o número de cartas de ofícios expedidas, não há dúvidas sobre seu estrondoso sucesso. Por outro lado, se formos analisar a inclusão desse grupo de operários no mercado de trabalho, haverá dificuldades, já que não existem estatísticas que possibilitem a verificação do número e do local onde os egressos efetivamente atuaram. Porém, essa empregabilidade não era o único objetivo do SENAI. Cremos que, através de seus cursos, o SENAI tentou 
construir uma classe operária industrial diferenciada, introduzindo os princípios da administração científica do trabalho, da psicologia aplicada e do capitalismo.

As escolas mantidas pelo SENAI apresentam grandes contradições com outras que oferecem ensino profissionalizante. Com relação à administração, as escolas técnicas profissionalizantes mantidas pelo Estado e pela rede particular são subordinadas exclusivamente ao MEC enquanto que as escolas SENAI subordinam-se tanto ao MEC (principalmente no cumprimento do Regimento Único, aprovado por aquele ministério) quanto ao Ministério do Trabalho (com quem melhor se afinam a CNI e sindicatos patronais). Quanto à formação dos alunos, enquanto as escolas ligadas exclusivamente ao ministério da Educação oferecem "o saber sobre o trabalho" na classificação de Kuenzer (1989), os alunos do SENAI recebem "o saber pelo trabalho", aprendendo, na prática, a executar determinadas funções e reproduzindo depois, no cotidiano profissional, uma rigorosa e bem treinada divisão de tarefas.

Outra diferença marcante com relação às outras escolas do país e também com escolas similares de outros países - nas quais os programas de formação profissional funcionam a partir da iniciativa dos industriais, com o apoio do Estado - no Brasil um determinado segmento da burguesia industrial assumiu o controle dos programas do Sistema $S^{17}$, que considerava vitais para o progresso industrial, minimizando o papel do Estado e excluindo completamente o operariado organizado.

Em 1961, foi promulgada a Lei 4.024/61 que manteve a dualidade estrutural entre a educação formal e a profissionalizante criando, entretanto, pela primeira vez, uma equivalência entre as duas estruturas e a integração dos dois níveis.

No período do milagre econômico não houve uma demanda excepcional da força de trabalho especializada, mas apenas a busca por treinamentos para formar trabalhadores necessários ao processo de ampliação do parque industrial. O SENAI reflete fortemente essa demanda, ao optar por cursos rápidos de qualificação, mantendo os cursos destinados à formação de trabalhadores especializados em crescimento vegetativo no período.

Em 1971, sob o regime militar, foi promulgada a lei $\mathrm{n}^{\circ}$ 5.692, que previa a profissionalização compulsória, estabelecendo a equivalência dos cursos do SENAI ao ensino regular. Na verdade, a equivalência se deu porque o SENAI já realizava a educação tecnicista proposta pela lei. Ao adotar a equivalência, o país poderia demonstrar, tanto aqui quanto no exterior, que estava ocorrendo um aumento na escolarização de segundo grau sem, entretanto, aumentar as despesas com verbas para essa modalidade de ensino.

A última Lei de Diretrizes e Bases da Educação Nacional, $n^{\circ}$ 9.394/96, tentando parecer moderna, introduziu os conceitos de flexibilidade, competências e habilidades, que significam, na prática, a tentativa de manter a perspectiva instrumentalista que sempre caracterizou a educação profissionalizante no Brasil, através da qual se tenta ocultar a luta de classes entre o capital e trabalho. Os artigos 39 a 42 do Capítulo II da referida Lei tratam da educação profissionalizante, estabelecendo mais claramente os objetivos para essa modalidade de ensino, definindo os três níveis da educação profissional: o básico (para o qual não se exige escolaridade prévia); o técnico (concomitante ou posterior ao ensino médio) e o tecnológico (egressos do Ensino Médio e Técnico), ou seja, a educação profissionalizante passa a ser articulada ao Ensino Médio, porém independente dele, resgatando a dualidade estrutural e a concepção taylorista-fordista que desvincula o saber acadêmico do saber prático, criando, ainda, categorias diferenciadas dentro de uma mesma formação.

\section{Conclusão}


A educação profissionalizante, presente no Brasil desde o período colonial, caminhou sempre na direção da filantropia, da benemerência ou da caserna.

Até o século XX, as reformas educacionais não conseguiram, de modo efetivo, abolir o abismo entre o ensino propedêutico e o profissional. É evidente que isso se dá porque a escola não pode ser considerada como um espaço de neutralidade; numa sociedade dividida em classes, o sistema educacional estará sempre difundindo um determinado projeto hegemônico.

O discurso do SENAI referente à busca pelo "conhecimento integral" poderia sugerir elementos que nos remetessem à educação politécnica, já que suas inúmeras publicações pregam insistentemente a necessidade da formação do homem "como um todo", do indivíduo "de forma global”. Porém, essa visão é equivocada, porque, pelo olhar histórico-dialético, sabemos que a formação politécnica valoriza a formação do indivíduo em sua totalidade, com acesso aos conhecimentos de formação geral (literatura, artes, matemática, música, história, geografia, ciências) e conhecimentos específicos (a partir de áreas do conhecimento científico socialmente elaborado), nos moldes pregados por Gramsci (2000).

Os três princípios vislumbrados por Marx e Engels para a educação da classe operária - educação pública, gratuita e educação para o trabalho - evitariam a alienação do trabalhador, estimulando sua participação da sociedade como indivíduo autônomo e consciente de seu papel.

No Brasil, não apenas o SENAI, mas as demais iniciativas voltadas à educação profissionalizante mantiveram-se separadas desse modelo de formação, com arremedos de cursos que minimamente transitavam pelos conteúdos da formação geral, o que descortina o lado cruel da formação para o trabalho, um modelo preocupado em satisfazer interesses imediatos que passa a predominar sobre a escola formativa, de modo não democrático, acabando por se constituir num fator adicional de perpetuação e cristalização das diferenças sociais. Nas palavras de Gramsci (2000, p. 49), não deveríamos "multiplicar e hierarquizar os tipos de escola profissional, mas criar um tipo único de escola preparatória (primária-média) que conduza o jovem até os umbrais da escolha profissional, formando-o, durante este meio tempo, como pessoa capaz de pensar, de estudar, de dirigir ou de controlar quem dirige".

Dermeval Saviani (2003, p.10) nos ensina que "a Politecnia diz respeito ao domínio dos fundamentos científicos das diferentes técnicas que caracterizam o processo de trabalho produtivo moderno. Está relacionada aos fundamentos das diferentes modalidades de trabalho e tem como base determinados princípios, determinados fundamentos, que devem ser garantidos pela formação politécnica". Para ele, a politecnia estaria fundamentada em princípios que a educação politécnica deveria garantir porque, ao dominar esses princípios e fundamentos, o trabalhador estaria em condições de desenvolver um trabalho compreendendo totalmente sua essência, dominando os princípios científicos nos quais se baseia a produção moderna. Não seria um trabalhador "adestrado" (ibidem) para servir ao mercado, mas sim um trabalhador com um "desenvolvimento multilateral [...] que abarca todos os ângulos da prática produtiva moderna" (ibidem).

A preocupação constante com a "formação integral do homem", para os dirigentes do SENAI era uma busca por "resgatar no homem todo seu potencial intelectual" para poder se tornar um cidadão "emancipado pelo trabalho". O operário "trabalhando em equipe, juntamente com a gerência" poderia, assim, assumir uma nova posição no processo de trabalho (SENAI, 1991a; 1991b e 1992). Também são recorrentes expressões que sugerem que, a partir de seus cursos, poderiam surgir novas relações de produção baseadas nas relações sociais, tais como "a automação e as mudanças na organização das indústrias 
levam a uma perspectiva mais humanista para o mundo do trabalho" (SENAI, 1999, p. 30) ou que "as novas formas de organização da produção enfraquecem a divisão do trabalho" (SENAI, 1999, p.10) ou, ainda, que seus cursos buscam "a superação dos tradicionais antagonismos inerentes ao taylorismo e ao fordismo" (SENAI, 1994, p.29).

À primeira vista, pode parecer que o SENAI estaria abandonando sua concepção centrada no "aprender pelo trabalho", deixando seu caráter ideológico de instituição técnica, formadora da mão-de-obra industrial, se voltando para o homem. Porém, analisando melhor esses dados, encontramos a explicação na pedagogia do industrialismo, na qual o "homem" é o elemento fundamental, devendo ter toda a atenção e condições de adequação ao local de trabalho, uma vez que a simplificação das funções e seu aprendizado por partes, torna muito mais fácil o recrutamento e a substituição de trabalhadores.

Quanto às relações sociais, não nos esqueçamos de que estas estão diretamente subordinadas ao modo de produção capitalista, que determina as classes antagônicas dos empresários (donos dos meios de produção) e dos operários (a força de trabalho). Marx (2007), mais uma vez, apresenta ferramentas para melhor compreendermos essas relações. Em "A Ideologia Alemã" Marx afirma que a primeira premissa de toda história humana é a existência de indivíduos reais, sendo sua constituição física o primeiro fato a ser registrado e, depois, o modo como eles estabelecem relações com o resto da natureza. A seguir, afirma que o processo de humanização é compreendido e analisado a partir da categoria trabalho, que é a característica distintiva e mais importante do homem em relação aos demais animais, estando o próprio processo de hominização intimamente ligado a essa categoria, podendo-se

distinguir os homens dos animais pela consciência, pela religião e por tudo que se queira. Mas a verdade é que eles próprios começam a se distinguir dos animais logo que começam a produzir seus meios de existência, e esse passo à frente é a própria consequiência de sua organização corporal. Ao produzirem seus meios de existência, os homens produzem indiretamente sua própria vida material. (MARX, 2007, p.10)

A organização do trabalho, entretanto, tende a dissociar o trabalhador do produto imediato do seu trabalho, passando sua contribuição a ter uma dimensão social e, portanto, um significado mediato e abstrato. O produto do trabalho do trabalhador passa a ser consumido de forma coletiva, por desconhecidos, sendo que, em alguns casos, somente será percebido e usufruído por gerações posteriores. Esse mecanismo muda a relação do trabalhador com o produto de seu trabalho e depende da exploração da mão-de-obra, num crescente processo de desumanização do trabalhador, em que "o trabalho está objetivado e o objeto trabalhado. O que do lado do trabalhador aparecia na forma de mobilidade aparece agora como propriedade imóvel na forma do ser, do lado do produto. Ele fiou e o produto é um fio" (Marx, 1983, p.151).

Assim, se as condições de trabalho são depauperadas, também o próprio homem será pauperizado, sendo sua exploração e alienação intensificadas. As dimensões propriamente humanas - a estética, a ética e a política - são consideradas fúteis, usufruídas por um pequeno grupo, como prêmio ou privilégio aos detentores do capital, um luxo inútil para os trabalhadores. O ser humano fica reduzido à sua vida animal, à satisfação de suas necessidades básicas de sobrevivência, somente sentindo-se ativo "nas suas funções animais - comer, beber e procriar, quando muito na habitação, no adorno, etc. - enquanto nas funções humanas se vê reduzido a animal" (Marx, 1983, p.162), servindo apenas como 
força de trabalho para que outros - os capitalistas - possam usufruir dos demais aspectos da existência. Marx ironiza

Quanto menos cada um comer, beber, comprar livros, for ao teatro ou ao baile, ao bar, quanto menos cada um pensar, amar, teorizar, cantar, pintar, poetar, etc., tanto mais poupará, tanto maior será o seu tesouro, que nem a traça nem a ferrugem roerão, o seu capital. Quanto menos cada um for, quanto menos cada um expressar a sua vida, tanto mais terá, tanto maior será a sua vida alienada (Marx, 1983, p. 210-220).

Portanto, o que se observa é que a escola, ao adquirir a finalidade de preparar para a adaptação à ordem social associada ao setor produtivo, desenvolvendo a disciplina, a submissão, a exatidão, a restrição à criatividade, relega para um plano secundário sua verdadeira finalidade de agente de modificação social. Assim, a preocupação do SENAI se explica se entendermos que, ao buscar o resgate da humanização dos indivíduos, o faz como uma visão técnico-utilitarista das relações de produção, nas quais o homem é elemento imprescindível.

Entretanto, essa vocação ideológica do SENAI não prejudicou sua imagem junto aos operários e líderes sindicais, sendo considerado por muitos como o único caminho de que dispunham para adquirirem uma profissão.

Seu slogan "Uma organização industrial a serviço do operário brasileiro" não esclarece, porém, que não estaria a serviço de todos os operários, mas sim de um grupo restrito, ao qual poderiam ser abertas as portas da realização individual, do emprego, do pertencimento ao universo industrial: os alunos do SENAI.

Finalizando, seu site nos informa que, nesses quase setenta anos de atividades "a média de 15 mil alunos dos primeiros anos transformou-se em cerca de 2 milhões de matrículas anuais, totalizando aproximadamente 43,2 milhões de matrículas desde 1942" (www.senai.br).

A permanência desse sistema de ensino profissionalizante por tanto tempo deve-se a vários fatores, sendo o principal a afinidade entre Governo e CNI, que propiciou a permanência nos órgãos dirigentes de representantes da elite industrial, a quem o Estado nunca enfrentou, passando sem dificuldades por mudanças político-ideológicas dos governos e pelos mais ou menos intensos movimentos operários. Da mesma forma, ao aceitar o SENAI como órgão representativo da educação profissionalizante convalidada pela CNI, a massa empresarial desobriga-se de quaisquer outras ações e contribuição, tanto ao Estado quanto aos órgãos representativos das indústrias.

Com respeito às funções docentes, majoritariamente ocupadas por técnicos, engenheiros, psicólogos e assistentes sociais, as contratações sempre estiveram atreladas a um rigoroso processo seletivo, sendo aceitos aqueles que demonstravam maior afinidade com a ideologia do Sistema $S$, com algumas raríssimas exceções, como Paulo Freire, que começou sua carreira docente como diretor do SESI de Recife sem nunca perder, entretanto, seu discurso e sua prática inovadores.

Sinal da mudança dos tempos, a partir dos anos de 1990, o SENAI passou a declarar uma valorização do conhecimento prévio trazido pelo operário, alegando que o aproveitamento das "competências pessoais" pode fazer com que o operário desempenhe melhor o seu trabalho, levando-o a compreender as rápidas mudanças tecnológicas que atualmente perpassam o processo produtivo. Segundo o SENAI, não se pode mais "esperar do trabalhador que repita gestos automáticos, hoje realizados por robôs; espera-se, do trabalhador atual, cada vez mais o domínio de conhecimentos. Cada vez menos, o domínio do gesto". (SENAI, 1992, p.06). 
Durante todo o ano de 2008, um novo embate entre o MEC, a CNI e o SENAI sobre a criação do FUNTEP - Fundo Nacional de Formação Técnica Profissional - levaram à divulgação de novos documentos. A proximidade dos fatos ainda não nos permitiu uma análise sobre seus desdobramentos, que culminaram com aquilo que se convencionou chamar na mídia de "um acordo bom para todos". Foi selado em 22 de julho de 2008 um termo de compromisso entre o governo federal e empresários, preservando a autonomia administrativa do Sistema S. O SENAI e o SENAC vão ampliar a oferta de cursos gratuitos, com o objetivo de chegar, até 2014, a utilizar dois terços de seu orçamento para isso.

Porém, a acirrada polêmica ainda não terminou. Certamente, em breve, mais uma vez, as forças se enfrentarão, cada qual tentando manter seu poder e a manutenção de suas posições, numa bifurcação cíclica que retorna de tempos em tempos: Estado ou Sistema S a quem caberá a responsabilidade pela formação profissional no país?

Não há uma resposta, mas podemos afirmar que a educação profissionalizante oferecida pelo SENAI transita entre o desejo das classes dominantes de se manterem no poder para, a partir dali, capacitar trabalhadores que elas mesmas utilizarão e o discurso da "prestação de serviços", através do qual tenta convencer (e muitas vezes consegue) a opinião pública de que pratica uma educação democrática e desinteressada.

\section{REFERÊNCIAS:}

ARISTÓTELES. Política. Disponível on line

em:http://www.planonacionaldeleitura.gov.pt/clubedeleituras/upload/e_livros/clle000021.p df Acesso em 20/06/2009.

BARBOSA, R. Obras completas de Rui Barbosa. Reforma do ensino primário e várias instituições complementares da instrução pública v.10 Rio de Janeiro: Ministério da Educação e Saúde, 1946.

BRANDÃO, Marisa. Da Arte do Ofício à Ciência da Indústria: a conformação do capitalismo industrial no Brasil vista através da Educação Profissional. In Boletim Técnico do SENAC (online) no 25, 2003. Acesso em 24/07/2006.

BRASIL - MEC Educação Profissional : Referenciais curriculares nacionais da educação profissional de nível técnico. Brasília, 2000.

Constituição dos Estados Unidos do Brasil de 10 de novembro de 1937.

Disponível:< http://www.planalto.gov.br/ccivil/Constituicao/Constitui\%C3\%A7ao37.htm Acesso em 24/10/2006.

, Decreto $\mathrm{n}^{\circ} 7.566$ - Crea nas capitaes dos Estados da Escolas de Aprendizes Artífices, para o ensino profissional primario e gratuito. 23/11/1909. Disponível em: http://portal.mec.gov.br/setec/arquivos/pdf3/decreto_7566_1909.pdf Acesso em 12/07/2006.

Decreto $\mathrm{n}^{\circ}$ 9.070, Dá novo regulamento ás escolas de aprendizes artífices. 25/10/1911. Disponível em http://www.camara.gov.br/sileg/integras/301564.pdf Acesso em 20/07/2006. 
Decreto $\mathrm{n}^{\circ} 19.560$ Aprova o regulamento que organiza a Secretaria de Estado do Ministério da Educação e Saúde Pública. 05/01/1931. Disponível em http://portal.mec.gov.br/arquivos/pdf/d19560.pdf Acesso em 24/07/2006.

BRYAN, Newton A.P. Educação e processo de trabalho: Contribuição ao estudo da formação da força de trabalho no Brasil. Dissertação de mestrado. UNICAMP: 1983.

CASTANHO, Sérgio. Educação e trabalho no Brasil colônia. Mimeo. Trabalho apresentado na sessão "Colóquios de História da Educação" do Grupo HISTEDBR Unicamp, 2006.

CIAVATTA, M. O trabalho como princípio educativo. In: Seminário Nacional de Formação - MST, realizado na Escola Nacional Florestan Fernandes, 2005.

CONCEIÇÃO, Marcelo R. A Educação nas ações e proposições do Instituto de Organização Racional do Trabalho (1932-1946). Dissertação de mestrado apresentada ao Programa de Estudos Pós-Graduados em Educação: História, Política e Sociedade, da PUC-SP São Paulo, 2005.

CUNHA, Luiz Antonio. O ensino industrial manufatureiro no Brasil. In: Revista Brasileira de Educação, São Paulo, nº 14, mai/jun/ago, 2000.

, O ensino de ofícios artesanais e manufatureiros no Brasil escravocrata $2^{\mathrm{a}}$ ed. São Paulo: Editora UNESP; Brasília, DF : FLACSO, 2005a.

O ensino de ofícios nos primórdios da industrialização. $2^{\mathrm{a}}$ ed. São Paulo: Editora UNESP; Brasília, DF : FLACSO, 2005 b.

FONSECA, Celso Suckow. História do ensino industrial no Brasil. 5 vols., $2^{\mathrm{a}}$ ed., Rio de Janeiro, SENAI/DPEA, 1986, vol. 1, p. 205.

GORENDER, Jacob. A burguesia brasileira. São Paulo: Brasiliense, 1981

GRAMSCI, Antonio. Cadernos do Cárcere. Vol. 2. Trad. Carlos Nelson Coutinho. Rio de Janeiro: Civilização Brasileira, 2000.

\section{IGNÁCIO, Paulo C. S. Da Educação Tecnológica à Formação Profissional: A}

Reforma do Ensino Técnico em questão. Niterói: UFF- Universidade Federal Fluminense.

Dissertação de Mestrado, 2000.

ISAÚ, M. Educação Salesiana no Brasil sudeste de 1880 a 1922: dimensões e atuação em diversos contextos. Campinas: Unicamp, 2006. Disponível on line em:

http://www.histedbr.fae.unicamp.br/navegando/artigos_frames/artigo_061.html 1976.

, O ensino profissional nos estabelecimentos de ensino dos salesianos. PUC/RJ,

KUENZER, Acácia Z. Pedagogia da fábrica: as relações de produção e a Educação do trabalhador. $3^{\text {a }}$ ed. São Paulo : Autores Associados , 1989.

LAURINDO, Arnaldo. 50 anos do ensino profissional no estado de São Paulo (19111961). $1^{\circ}$ volume São Paulo: Editora Gráfica Irmãos Andrioli S/A, 1962.

LÜDERITZ, J. Relatório. Apresentado a Miguel Calmon Du Pin e Almeida, Ministro da Agricultura, Indústria e Comércio. Rio de Janeiro: Oficinas Gráficas da Lito - Tipografia Fluminense, 1925.

MANGE, Roberto. Lições de Psicotécnica. São Paulo: IDORT, 1934. 
MARTINS, Mônica S.N. Entre a cruz e o capital: mestres, aprendizes e corporações de ofícios no rio de janeiro (1808-1824) tese de doutorado. Rio de Janeiro: UFRJ, 2007.

MARX, K., O Capital: Crítica da Economia Política. Livro Primeiro vol. 1 - O processo de produção do Capital. Coleção Os Economistas - São Paulo: Abril Cultural, 1983.

MARX, K. e ENGELS, F. A ideologia alemã. Disponível on line em:

http://www.pstu.org.br/biblioteca/marx_ideologia.pdf 2007. Acesso em 14/09/2007.

MORAES, Carmen S.V. A socialização da força de trabalho: Instrução popular e qualificação profissional no estado de São Paulo - 1873/1934 - tese de doutorado, USP, 1990.

OLIVEIRA, M.A.M. A Reforma do ensino profissional: desmantelamento da educação tecnológica ministrada pelo CEFET - PUCMG (s.d).

QUELUZ, Gilson. Concepções de ensino técnico na República Velha (1909-1930). Curitiba: Cefet-Paraná, 2000.

RAGO, Luzia e MOREIRA, E.F. P O Que é Taylorismo, $1^{\text {a }}$ Ed. Coleção Primeiros Passos, São Paulo: Brasiliense, 1984.

SALESIANOS. A pedagogia de Dom Bosco através de seus escritos, São Paulo: Ed. Salesiana, 1987.

SAVIANI, Dermeval. As concepções pedagógicas na história da educação brasileira. Texto elaborado no âmbito do projeto de pesquisa $O$ espaço acadêmico da Pedagogia no Brasil HISTEDBR : 2005.

A nova lei da educação: LDB trajetória, limites e perspectivas. Campinas, SP : editora Autores Associados, 1999.

O Choque Teórico da Politecnia. Apresentado no seminário Trabalho, Educação e Saúde. Campinas: Unicamp, 2003. Disponível em

http://www.diaadia.pr.gov.br/det/arquivos/File/SEMANAPEDAGOGICA/21_O-choque-teorico-dapolitecnia-Saviani.pdf Acesso em 20/11/2008.

SENAI, Projeto Memória. De homens e máquinas: Roberto Mange e a formação profissional. Volume 1. São Paulo: SENAI, 1991a.

.. De homens e máquinas: Acervo Roberto Mange. Inventário Analítico. São Paulo: SENAI, Projeto Memória 1991b.

, O Giz e a Graxa : meio século de educação para o trabalho. São Paulo : SENAI, Projeto Memória. 1992.

Ação Estratégica número 1 - Reestruturação dos Modelos de formação profissional no SENAI. Assessoria de Planejamento. Departamento Nacional - Rio de Janeiro, ago. 1994.

65 anos de um sistema educacional conseqüente. São Paulo: SENAI, 2007.

WEINSTEIN, Bárbara. The Model Worker of the Paulista Industrialists: The Campanha

Operário-Padrão 1964-1985. Revista Radical History Review, nº 61, 1995.

(Re) formação da classe trabalhadora no Brasil (1920-1964).São Paulo: Cortez. Universidade São Francisco, 2000. 


\section{SITES CONSULTADOS}

www.jus.com.br/doutrina Acesso em 02/03/2010

www.senai.br Acesso em 20/01/2007

\section{NOTAS}

${ }^{1}$ Fonseca (1986) apresenta uma interessante teoria sobre o surgimento dos serviços públicos: as elites agrárias, por orgulho de terem filhos "doutores" os encaminhavam aos cursos de bacharelado na Europa. Ao se formar, os jovens não tinham conhecimento prático suficiente para dar continuidade ao trabalho do pai, na administração das fazendas, mudando-se, assim, para os centros urbanos, passando da classe produtora de riquezas para a de consumidora, porém, sem emprego. Como os pais eram influentes, conseguiam-lhes colocações no serviço público, fazendo com que o Estado se visse obrigado a, nas palavras de Rui Barbosa (1946), "alargar gradualmente suas repartições" para acomodar os cidadãos sem emprego por ele mesmo formados.

${ }^{2}$ Os estudos de Martins (2007) apontam que essas agremiações eram extremamente fortes e influentes. Como exemplo, cita um movimento engendrado pela Irmandade de São Crispim e São Crispiniano (Corporação dos sapateiros) exigindo o cumprimento de um ofício real português de 1764 que proibia a venda de sapatos pelas ruas do Rio de Janeiro. Não obtendo resposta, em 1813 foi encaminhada uma carta diretamente ao Príncipe Regente, criticando a venda em praça pública de obras feitas dentro de casas, criticando ainda o comércio de sapatos por pessoas não pertencentes à Corporação dos sapateiros, solicitando sua prisão, além de uma multa a ser destinada em parte à irmandade. Anexaram à carta um abaixo-assinado relatando "os inconvenientes, que se seguião à mesma Irmandade, aos mais suplicantes, e athe ao Publico de se venderem pelas ruas obras feitas em cazas particulares por escravos captivos, mulheres e pessoas imperitas". Totalizavam cento e uma assinaturas a favor de que fossem fixados novos editais pelas ruas da cidade do Rio de Janeiro proibindo a venda de calçados. Essa reivindicação, seguida depois nos mesmos moldes por outras Corporações, mostra, além de uma relativa organização, o desejo de minimizar vendas que fossem contra os interesses dos que contribuíam regularmente com a entidade, dos que seguiam as regras e os compromissos dos artesãos. Mostra ainda a reação quando se feria o controle que o mestre artesão tinha sobre a produção de calçados e o prejuízo comercial causado pela forte concorrência com artigos estrangeiros que passaram a entrar na colônia a partir da chegada da Família Real.

${ }^{3}$ Os Liceus surgiram na França no século XVIII, para ensinar artes e ofícios. O nome pretendia indicar um local de efervescência cultural, já que Liceu era o ginásio de Atenas onde Aristóteles ensinava.

${ }^{4}$ Segundo Cunha (2005b) o Liceu de Artes e Ofícios de São Paulo teve um desenvolvimento maior que todos os outros devido à presença, nos quadros dirigentes e no corpo docente, de membros da Escola Politécnica de São Paulo, o que propiciou destinação de recursos públicos e privados à instituição, que pode abrir e manter várias oficinas.

${ }^{5}$ Giovanni Melchior Bosco - nascido a 16/08/1815 em Becchi, Itália, foi ordenado padre em 1841, no período mais efervescente da revolução industrial. Dedicou-se aos jovens abandonados, "produtos da era da industrialização" que saíam em busca das cidades. Faleceu em 1888 deixando 14 escolas profissionalizantes na Itália, França e Alemanha. Para mais informações ler: A pedagogia de Dom Bosco através de seus escritos, São Paulo: Ed. Salesiana, 1987.

${ }^{6}$ Para uma análise mais aprofundada sobre a presença salesiana na educação brasileira, ver a dissertação de mestrado de ISAÚ, Manuel $O$ ensino profissional nos estabelecimentos de ensino dos salesianos. PUC/RJ, 1976

${ }^{7}$ Em 1942, pelas assim chamadas "leis orgânicas da educação" essas escolas foram transformadas em escolas industriais de nível pós-primário.

${ }^{8}$ Pelo Decreto 24.558 de 03/06/34.

${ }^{9}$ Taylorismo ou Organização Científica do Trabalho é o modelo de administração defendido pelo engenheiro americano Frederick Taylor (1856/1915) no final do século XIX que propunha o parcelamento e cronometragem de cada fase do trabalho, com foco sobre a eficiência e eficácia operacional na administração industrial. Sua 
teoria, embora representasse economia para a empresa, gerou polêmicas por desumanizar os operários, reduzindo-os a máquinas. Ler RAGO, Luzia e MOREIRA, E.F.P O Que é Taylorismo, $1^{\mathrm{a}}$ Ed. Coleção Primeiros Passos, São Paulo : Brasiliense, 1984.

${ }^{10}$ O IDORT foi responsável pela estruturação do Centro Ferroviário de Ensino e Seleção Profissional (CFESP), em 1941 e em 1942 participou da elaboração do projeto de criação do Serviço Nacional de Aprendizagem Industrial (SENAI).

${ }^{11}$ Em 1932, alguns intelectuais redigiram o documento conhecido como "Manifesto dos Pioneiros da Educação Nova" que se tornou o marco inaugural do projeto de renovação educacional do país.

12 Segundo Ignácio (2000, p.48), a Reforma Capanema manteve a educação no mesmo degrau em que se encontrava, sendo que "aos cidadãos de 'primeira categoria' ou à futura elite dirigente (os 'tomadores de decisões'), era reservada a seqüência: primário, ginasial, estudos livres, exames e um curso superior; aos cidadãos de 'segunda categoria', que iriam desempenhar funções intermediárias na divisão técnica e social do trabalho, eram reservadas as seqüências: primário, ginásio e $6{ }^{a}$ série; ou primário, adaptação e normal; ou ainda primário, preparatório e técnico comercial. Para os cidadãos de 'terceira categoria', que teriam funções 'menos intelectualizadas' no processo produtivo, eram reservados os cursos rural, seguido do básico agrícola ou profissional, seguido do complementar".

${ }^{13}$ Método criado e aplicado pelo físico-matemático russo Victor Karlovich Della-Vos (1829/1890). Tendo se graduado em 1953, foi a Paris para estudar a construção de máquinas automotivas. Apaixonado pela mecânica, também esteve em Londres para estudar a construção de máquinas agrícolas. Em 1868, como diretor da Escola Imperial Técnica de Moscou, desenvolveu e aplicou um método baseado nas assim chamadas "séries metódicas", para ensinar aos alunos, num curto período de tempo, as funções necessárias à manutenção da rede ferroviária russa. O capítulo 3 de nossa tese de doutoramento mostra um conjunto de SMO, apresentando uma explanação sobre sua utilização e avaliação. MÜLLER, Meire T. A lousa e o Torno: A Escola SENAI Roberto Mange de Campinas. UNICAMP, 2009.

${ }^{14}$ Lourenço Filho foi particularmente influenciado pela psicotécnica. Em 1931, à frente da Diretoria Geral de Ensino, desenvolveu seus famosos Testes $A B C$ baseados na psicotécnica para qualificar as crianças, distribuindo-as pelas turmas de acordo com seu desempenho.

15 Embora este artigo não pretenda aprofundar-se no estudo do sistema educacional do IDORT, é importante salientar que o referido Instituto, para a educação, propunha uma integração entre a seleção, orientação e formação profissional, o que demonstra a existência de um projeto mais amplo do que indicam os estudos feitos sobre os cursos profissionalizantes ofertados por ele. Conceição (2005 p. 7) afirma que "ao isolar o ensino profissional de outras instâncias, como no caso da orientação profissional e da seleção profissional, perde-se o escopo principal de um projeto que tinha na escola um de seus alvos preferenciais e que ampliando a profissionalização, com a utilização de exames psicotécnicos, provas de seleção para o ingresso e ensino de caráter científico, provar-se-ia a sua eficiência, em relação ao ensino tradicional".

${ }^{16}$ Um relatório elaborado por médicos ingleses durante a $2^{\text {a }}$ Grande Guerra colocava em dúvida a psicotécnica, uma vez que não se pôde comprovar cientificamente nenhuma relação entre o desempenho dos pilotos da Royal Air Force e o resultado dos testes psicotécnicos a que tinham sido submetidos.

${ }^{17}$ No sentido estrito, o "Sistema S" não existe. Etimologicamente, entende-se por sistema uma organização de elementos para a consecução de um objetivo comum e, na realidade, o único elo que une as instituições participantes do Sistema S, além do seu patrocínio pela burguesia, é o modelo de contribuição compulsória sobre a folha de pagamento das empresas, sendo que seus objetivos são distintos. São consideradas integrantes do Sistema S nove instituições: SESI e SENAI (indústria), SESC e SENAC (comércio), SENAR (agricultura), SESCOOP (cooperativas), SEST e SENAT (transportes) e SEBRAE (micro e pequenas empresas).

Artigo recebido em: 26/10/2010

Aprovado em: $19 / 12 / 2010$ 